\title{
Evaluation of the Possible Integration of Uzbekistan into the EAEU with Reference to the Country's Joining the WTO
}

\author{
Olimjonov Odil Olimovich
}

\begin{abstract}
The introduction of a favorable visa regime for Uzbeks will make it easier for them to move not only to work in the union, but also to live. This will allow Uzbekistan, which has a relatively dense demographic position, to effectively distribute its population across the Union countries. In addition, Uzbeks will become full members of citizens, working on equal terms and with the same rights as citizens of other countries. For example, citizens of a member state of the EAEU have the right to work without obtaining a patent, that is, without paying a patent fee. However, they are required to undergo temporary registration (registration) at the place of residence. Of course, it is the law of every country that any person (even as a tourist) must inform the appropriate authorities about their place of residence. The exemption from the payment of patent fees in many respects requires cooperation with the union.
\end{abstract}

Index Terms - world economy, international trade, Uzbekistan.

\section{INTRODUCTION}

Within the framework of raising global competition in the world, economic integration with other states is becoming the most essential source and reserve of economic growth for almost all countries.

Due to the significant potential of this factor, new integration communities between states have already been created in the world and, most probably, will be further established as well. Thus, currently there are very powerful integration associations and the share of the nine largest of them (EU, ASEAN, NAFTA, MERCOSUR, BRICS, CIS, SCO, EAEU, South African Customs Union) constituted $73.6 \%$ of all world exports of goods and services in 20181.

Therefore, the entry of Uzbekistan into the EAEU has economic factors that are crucially important for this country2. However, in order to provide a reasonable

Published on October 30, 2020.

Olimjonov Odil Olimovich, Doctor of Economics, Professor, Project leader of the Institute for Forecasting and Macroeconomic Research under the Ministry of the Economic Development and Poverty Reduction of the Republic of Uzbekistan, Uzbekistan.

(corresponding e-mail: dilshodjon.rakhmonov@mail.ru)

1 Calculated by the author on the basis of https://data.worldbank.org/indicator/BX.GSR.GNFS.CD.

It should be reminded that some countries simultaneously participate in two, three, in rare cases, even in four economic communities. Due to this, the indicators of export-import of such member countries of the communities have been taken into account once and this factor should be taken into consideration.

${ }^{2}$ Currently (in 2020) the Republic of Uzbekistan is joining the EAEU as an observer country. However, the author thinks that in the future evaluation of possible benefits and risks of the entry of Uzbekistan into the EAEU, it is required to determine the scale of the common market and the level of economic relations between the country and the member states of this Union.

\section{ANALYSES AND RESULTS}

The total area of the territory of the EAEU countries is 20.3 million square kilometers, the population accounts for 186 million, and the GDP amounts to 1.9 trillion USD. It should be noted that the EAEU is a large-scale market and has great opportunities. In addition, in 2018 the share of exports of Uzbekistan accounted $28.3 \%$ in the EAEU countries and the share of imports constituted $28.7 \%$. This factor illustrates actual significance of these countries for its economy and the relevance of Uzbekistan entry into it (see Table 1).

Joining the EAEU enables to use the following potential benefits and new opportunities for the economy of Uzbekistan as a whole:

- reducing prices for goods, due to a decrease in the cost of transporting raw materials or exporting finished products;

- promoting robust competition within the common EAEU market;

- as a result of reducing costs and raising labor productivity, an increase in average salary;

- production increase due to the growth of demand for goods;

- accelerating the country's shift to an export-oriented development model, there is an opportunity to create job places in export-oriented sectors of the economy;

- enhancing the welfare of the population of the EAEU countries due to lower food prices and increased employment of the population;

- an increase in the payback of new technologies and products due to the market expansion.

Moreover, unification of the industrial, transport, industrial base, human resources will provide a multiplier effect to all EAEU members.

Uzbekistan will become a full member of this organization. Therefore, this article deals with the positive and negative factors of the possible integration of the Republic of Uzbekistan into the EAEU, taking into account its entry into the WTO. 


\begin{tabular}{|c|c|c|c|c|c|c|c|c|}
\hline & \multirow{2}{*}{ Total } & \multicolumn{5}{|c|}{ Including: } & \multirow{2}{*}{$\begin{array}{l}\text { Total, EAEU } \\
\text { members }\end{array}$} & \multirow{2}{*}{$\begin{array}{l}\text { Share of the } \\
\text { countries - } \\
\text { EAEU } \\
\text { members, in } \\
\%\end{array}$} \\
\hline & & Russia & Kazakhstan & Belarus & Kyrgyzstan & Armenia & & \\
\hline $\begin{array}{l}\text { Export, } \\
\text { million USD }\end{array}$ & 13990,8 & 2192,9 & 1457,7 & 41,3 & 269,7 & 2,7 & 3964,3 & 28,3 \\
\hline $\begin{array}{l}\text { Import, } \\
\text { million USD }\end{array}$ & 19562,3 & 3536,9 & 1564,5 & 377,2 & 133,1 & 2,8 & 5614,5 & 28,7 \\
\hline $\begin{array}{l}\text { Foreign } \\
\text { economic } \\
\text { turnover, } \\
\text { million USD }\end{array}$ & 33553,1 & 5729,8 & 3022,2 & 418,5 & 402,8 & 5,5 & 9578,8 & 28,5 \\
\hline
\end{tabular}

million USD

Source: Calculated by the author on the basis of the "Statistical Bulletin "Export-Import of Goods and Services for 2018" of the State Committee of the Republic of Uzbekistan on Statistics.

With the aim of clear vision of the possible consequences of Uzbekistan entry into the EAEU, it is advisable to analyze this issue separately on financial and customs issues, industry, agriculture and labor migration, which in the national conditions are most sensitive to changes in economic policy.

Potential benefits from joining the EAEU by Uzbekistan in the field of financial, monetary and customs issues:

- transnational authority on regulation of the EAEU financial market will be created in 2025;

- creation of the EAEU investment bank is scheduled;

- the EAEU intends to develop a single stock market and a loan capital market;

- regarding foreign exchange market, solving this problem requires a long period of time for preparation and gradual implementation to the extent as required conditions are created for changing national monetary system;

- the country independently sets customs duties in relation to third countries, which enables to allows pursuing the policy of industrialization and modernization of the economy;

- low or zero customs duties within the EAEU promote the implementation of the reserves of Uzbekistan trade potential with the participating countries, which results in the increase in trade turnover and production growth;

- trade development of within the zone will provide an incentive to diversify not only the commodity structure of the national exports and imports, but also the geographic focus of trade, which, in turn, makes a positive effect on the dynamics of trade and macroeconomic development of the national economy;

- exempt, custom-free access to the markets of the EAEU countries can accelerate the entry of Uzbekistan into more global economic communities, for example, into the WTO. Herewith there is created an opportunity to enter the markets of large countries in industries where Uzbekistan has a comparative advantage over other EAEU countries.

The main risks in this area are associated with the following problems:

- deterioration of the trade balance due to a decrease in the possibilities of tariff and non-tariff restrictions on imports within the framework of integration agreements;

- problems of exchange rates parity and increased dependence of monetary policy on external shocks in the EAEU member countries;

- reduction in the competitiveness of the national economy sectors due to more developed incentive tools in neighboring countries;

- deterioration in the exports structure (raw materials predominance, energy inputs).

In general, the stock markets of the EAEU countries are characterized by uneven development, which can negatively affect financial integration. However, despite the uneven development, stock markets can achieve the greatest efficiency when they are merged into a single stock exchange within the EAEU. In this regard, it is necessary to unify current legislation with the EAEU countries requirements, solve problems on the development and implementation of new mechanisms for regulating their activities, and create a developed infrastructure.

In general, among the EAEU countries, credit institutions of Russia and Kazakhstan have the main advantages. It can be assumed, that cooperation and market share in the banking sector of the five countries will slowly grow in reliance upon mutual trade and economic efficiency. This is due to the fact that currently the process of opening subsidiary banks and representative offices between Russia, Kazakhstan and Belarus is going on.

The main positive effects of possible integration for industrial enterprises will be the following:

- reducing the price of manufactured goods by decreasing customs duties, transportation costs of required imported raw materials, and most importantly, keeping the export price of goods at a competitive level;

- production increase due to the growth of demand for manufactured goods;

- increase in investment inflow to the industrial sector;

- reducing prices for purchased technologies, and, as a result, raising their payback;

- expanding opportunities for purchasing energy efficient technologies

\section{Negative impact in industry:}

- due to abolishing customs duties, financial position of individual manufacturers and exporters of industrial products may deteriorate as the import of these products from three countries - the main participants of the EAEU (Russia, Belarus and Kazakhstan) already possesses a large share in the national market of industrial products;

- there may be the risks of an increase in the volume of imports of cheaper and better quality petroleum products, mineral fertilizers and other types of industrial products;

- there is possibility of reducing previously established quotas and customs barriers for the import of certain types of imported industrial products;

- even in the medium term, there may also be restrictions 
on the export of gas processing and petrochemical products due to factors ensuring a higher competitiveness of similar products produced in the EAEU countries.

Positive effects in the agriculture are the following:

- reducing prices for imported agricultural machinery, technologies, seeds, fertilizers, chemical protection products, medicines for cattle breeding and other means required for the agriculture development;

- growth in foreign exchange earnings from the export of agricultural products to the EAEU countries;

-improving logistics and shortening the delivery time of agricultural products will make an impact on maintaining the quality and condition of crop products delivered to the market of the EAEU countries.

Negative impacts on the agriculture are the following:

- due to abolishing customs duties, financial situation of individual producers and exporters of agricultural products may worsen, as the import of these products from three countries - the main members of the EAEU (Belarus, Kazakhstan and Russia) is constantly growing;

- the occurrence of re-export cases from the EAEU countries to Uzbekistan of those types of agricultural products of third countries for which the import customs duty in the EAEU is lower than in Uzbekistan;

- nonconformity of food products with strict phytosanitary measures can prevent export growth. In this regard, since January 1, 2015, amendments were introduced to the rules for importing quarantineable products into Russia in accordance with the Federal Law "On Plant Quarantine". Fresh and dried fruits and vegetables, herbs, dried herbs, tea, nuts, etc. are considered to be quarantineable products.

Labor migration consequences for Uzbekistan:

- reduction of quotas for the migrant workers entry under contracts to the territory of the EAEU may create significant constraint in the domestic labor market of Uzbekistan. In addition, this may affect the reduction in the volume of remittances;

- even in the nearest future, Kazakhstan may challenge a shortage of qualified personnel, which facilitate attracting qualified specialists. This may affect the increase of their outflow from Uzbekistan. Such conditions may cause migration (outflow) of workers of engineering specialties with higher education from Uzbekistan;

- once the single market is established, licenses and permits for doing business will be admitted by all member countries, which will create an additional labor market to attract both qualified and unskilled specialists from "third parties" to the regions with favorable business conditions. For migrants from Uzbekistan, mainly, it can be Kazakhstan.

\section{CONCLUSION}

When evaluating all positive and negative aspects of the possible entry of Uzbekistan into the EAEU, it is possible to summarize the following: joining the EAEU is economically beneficial for the Republic of Uzbekistan. The most important thing in this matter is to prepare as best as possible for joining the EAEU.

Regarding possible entry of Uzbekistan into the EAEU, there is another very serious question: how will this process influence the country's entry into the WTO?

First of all, I would like to answer those who believe or think that entry of Uzbekistan into the EAEU creates additional difficulties for it when it joins the WTO and that's definitely true. Indeed, after the Republic of Uzbekistan becomes a member of the EAEU, additional questions will arise concerning its entry into the WTO. However, I would like to remind them that the absolute majority of the WTO member countries are simultaneously members of other regional economic communities. It must be admitted, that these countries, more than the others, which were not members of other economic associations, were preparing to join the WTO, and the most important thing, that they have succeeded. For example, Russia, Kazakhstan and Kyrgyzstan are members of the EAEU and the WTO. I hope that Uzbekistan will succeed as well.

Some WTO members have concerns that after joining the EAEU, Uzbekistan may reduce economic relations with the WTO members. Such fears are motiveless and ungrounded, since the Republic of Uzbekistan has taken a consistent focus on becoming a developed state in the future. To pursue this aim, it will continue to purchase high technology, high-performance machines and mechanisms, modern construction materials, communications, etc. from developed countries. This implies that one thing does not interfere with the other one!

In the long term, Uzbekistan sets itself the goal of joining the WTO. However, due to economic reasons, the entry of Uzbekistan into the EAEU in the nearest future is more preferable than joining the WTO, since the competition within the WTO is sharper and tougher than within the EAEU. Thus, the possibility of Uzbekistan joining the EAEU should be considered within the framework of the country's preparation for joining the WTO.

\section{REFERENCES}

[1] Calculated by the author on the basis of https://data.worldbank.org/indicator/BX.GSR.GNFS.CD.

[2] It should be reminded that some countries simultaneously participate in two, three, in rare cases, even in four economic communities. Due to this, the indicators of export-import of such member countries of the communities have been taken into account once and this factor should be taken into consideration.

[3] Currently (in 2020) the Republic of Uzbekistan is joining the EAEU as an observer country. However, the author thinks that in the future Uzbekistan will become a full member of this organization. Therefore, this article deals with the positive and negative factors of the possible integration of the Republic of Uzbekistan into the EAEU, taking into account its entry into the WTO. 